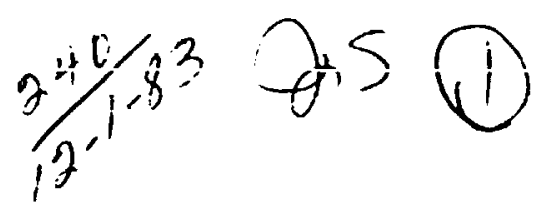

Dr. 195?-7 ORNL/FEDC-83/5

\title{
ENGINEERING ASPECTS OF DISRUPTION CURRENT DECAY
}

J.G. MURRAY

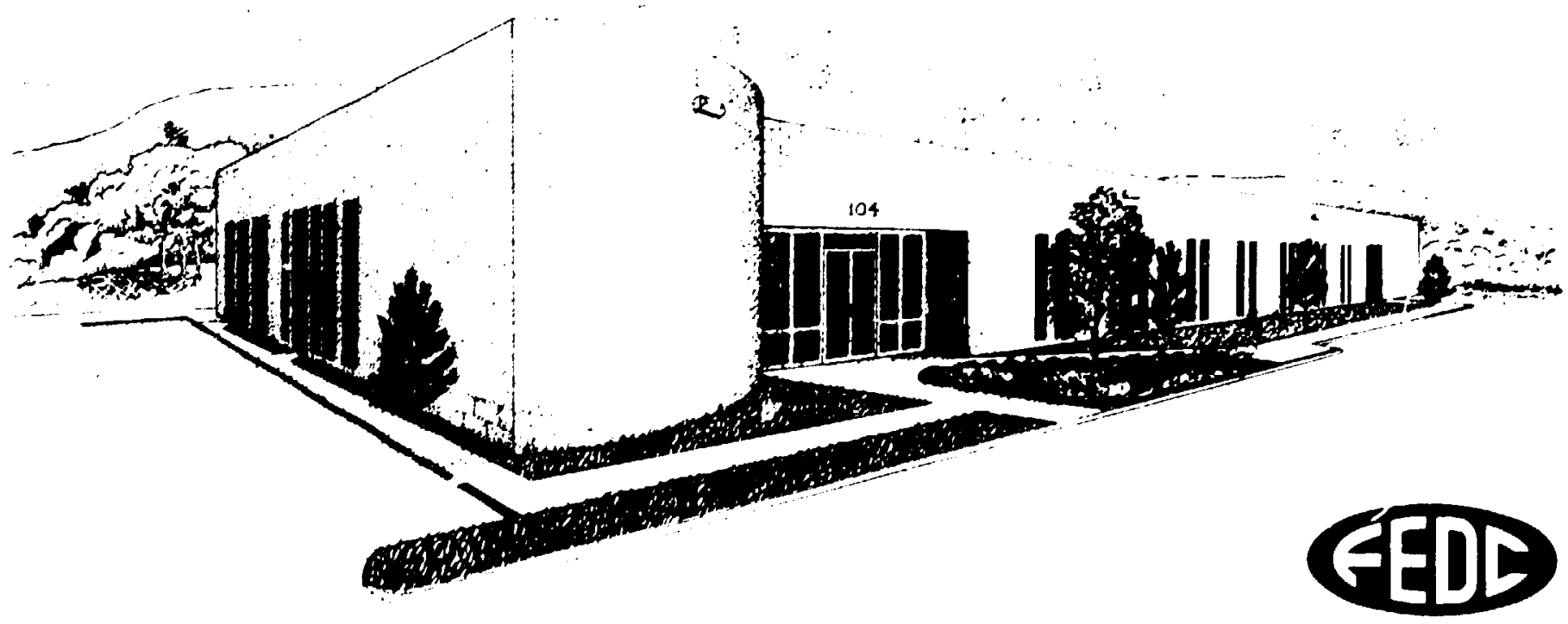

FUSION ENGINEERING DESIGN CENTER

Oak Ridge National Laboratory * Oak Ridge, Tennessee 


\begin{tabular}{|c|}
\hline Printed in tre United States of America Available from \\
National Techrical Information Service \\
U.S. Dopartinent of Commerce \\
5285 Port Royal Road. Springfieli. Virginia 22161 \\
NTIS price codes-Printed Copy A03 Microfiche F01 \\
\hline
\end{tabular}

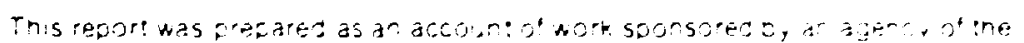

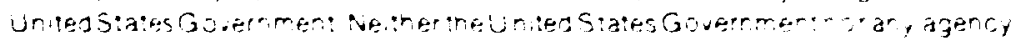

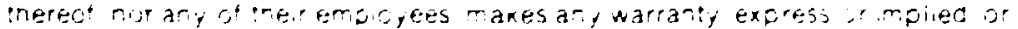

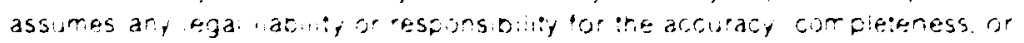
wetuiness of any mtormation apparatus prorece or process disclosec or

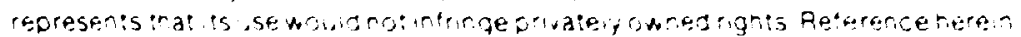

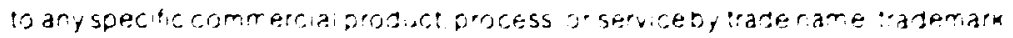

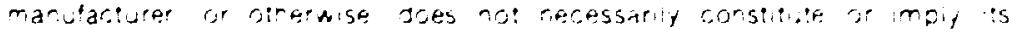

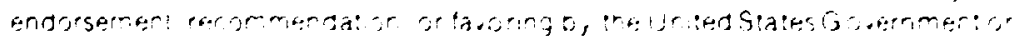

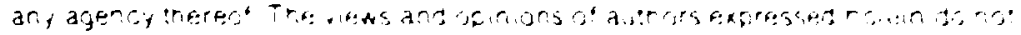

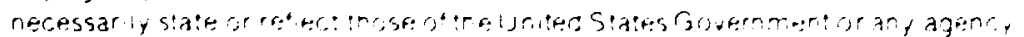
inerent 


\section{DISCLAIMER}

This repont was prepared as an ecoount of work sponered by an afeocy of the United States Government. Neither the United States Governmeat sor any afency theroof, nor any of their employees, malues any warranty, expres or implied, or asumes any legal libbitity or responsiblity for the socuracy, completeness, or uefulaces of any information, apparatis, product, or proces disclowed, or represents that its we woald ool infringe privately owned rights Reference hevin to any specific ranmercial product, process, or service by trade name, trademart.

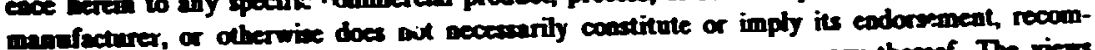
meadation, of favoring by the United Stnles Government or any agency thereof. The views and opinions of anthors expresed bercin do not pucaurily state of reflect those of the United Stutes Govermment or any aseacy thereof.

Fusion Energy Division

ORNL/FE $)$ C $-83 / 5$

Dist. Category IIC-20 c,d

ENGINEERING ASPECTS OF DISRUPTION CURRENT DECAY

J. G. Murray

Fusion Engineering Design Center

Date Published - November 1983

Prepared by the

OAK RIDCF, NATIONAL LABORATORY

Oak Ridge, Tennessee 37830

operated by

UNION CARBILF: CORPORATION

for the

DEPARTMEN" OF ENER(j)

under contraci $W$-i105-eng-26 


\section{CONTENTS}

ABSTRACT . . . . . . . . . . . . . . . . . iv

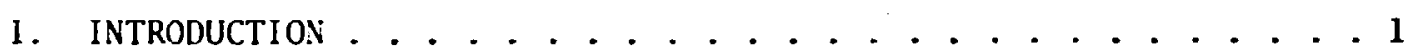

2. ENGINEERING FEATURES . . . . . . . . . . . . . . . 2

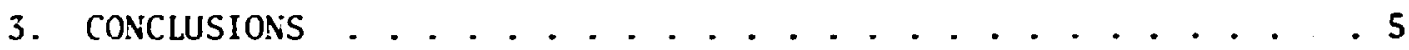

Appendix $A$. DESIGN OPTIONS FOR REDUCING DISRUPTION DAMAGE . . . 7

REFERE.SCES ........................... 10 


\begin{abstract}
Engineering features associated with the configuration of a tokamak can affect the amount of energy that produces melting and damage to the Iimiters or internal wall surfaces as the result of a major disruption. During the current decay period of a major thermal disruption, the energy that can damage a wall or limiter comes from the external magnetic field. By providing a good conducting torus near the plasma and increasing the plaswa circuit resistance, this magnetic energy (transferred by way of the plaswa circuit) can be minimized. This report addresses engineering design features to reduce the energy deposited on the inner torus surface that produces melting of the structures.
\end{abstract}




\section{INTRODUCTION}

Disruption has been a major problem in experinental efforts associated with tokamak plasma physics. Present machines have not been designed to withstand major disruptions. Therefore, the prinary effort has been to learn how to avoid them in order to prevent a large influx of impurities and the damage that results in a machine shutdown. The second nost important effort has been to gain an understanding of how disruptions start and how to prevent them. This paper considers only the engineering features associated with the current decay phase of the disruption. The main emphasis will be on how to minimize the danage for the worst-case condition on future large fusion devices.

There is an assumed understanding that increasing disruption time is a desirable goal. This is partially true fur the current decay phase, but not true for the thermal decay phase. If a major thermal disruption occurs, the thermal energy in the core of the plasma is transferred to the outer surface of the plasma. The predominant portion of the energy will be deposited on the limiter or on whatever is in contact with the plasma. The plasma radial position does not change greatly during this phase of the disruption, and there is not a large change in plasma current magnitude. If the thermal decay occurs very fast, the material in contart with the plasma edge will ablate and there will be a loss of surface material. If, however, the thermal decay time is long (milliseconds instead of microseconds), the surface material will melt and the electromagnetic forces can displace the liquid metal. This will result in a much larger loss of surface material. 1

The advantage of a long disruption time is in the current decay phase. This is intuitively understood, but the specifics have noc always been determined. The decay of the external magsetic field should be long, although not necessarily the deray time of the plasma current. After the thermal disruption time has elapsed (less than 125 us in Doublet $(I I)^{2}$, the energy remaining is primarily in the magnetic field external to the plasma. If this energy can be deposited 
in the bulk of a vessel as $I^{2} R t$ energy, damage resulting from the current decay need not occur. How fast the plasma curreric decays urser these conditions is not important.

\section{ENGINEERING FEATURES}

The vessel electromagretic design features should be

(1) a low impedance vessel, close :0 the plasma and

(2) enhanced toroidal current patts and poor radial current paths in the vessel structure.

The low impedance current path allows vessel currents to support the external field in the event of a disruption and to dissipate the energy in ohmic heating of the vessel. Radial currents are not desired because they interact with the intense toroidal fields and produce high forces. The toroidal currents are at right angles to the lower intensity poloidal fields; hence, the resultant forces are an order of magnitude lower than for radial currents. The low impedance path near the plasma eliminates th possibiljty of inducing high voltages in the poloidal field $c$ ils and insulation breakdown due to disruption, it eiminates the possibility of arc voltages developing and the resultant arc erosicn, and it reduces tl. eddy current heating in the superconducting coil structure and the possibility of driving the superconductors normal during a disruption. Finally, a good conducting shell near the plasma provides self-position control stabilization. This results in a minimun-size active position control system.

To further understand the advantage of or need for a good conducting wall or sets of toroidal conductors as close to the plasma as possible, the two cases in Fig. 1. can be analyzed. In case A, there is no conducting vessel near the plasma, only two internal limiters. If the magnetically stored energy is $100 \mathrm{MJ}$, the approximate value for future tokamaks, then a current disruption in case A will result in essentially $100 \mathrm{MJ}$ being deposited on the surface of the limiters. The energy per unit area will be large, and excessive melting and loss of material can occur. Note that the bulk of the magnetic energy is deposited as thermal energy on the limiters. As the plasma 


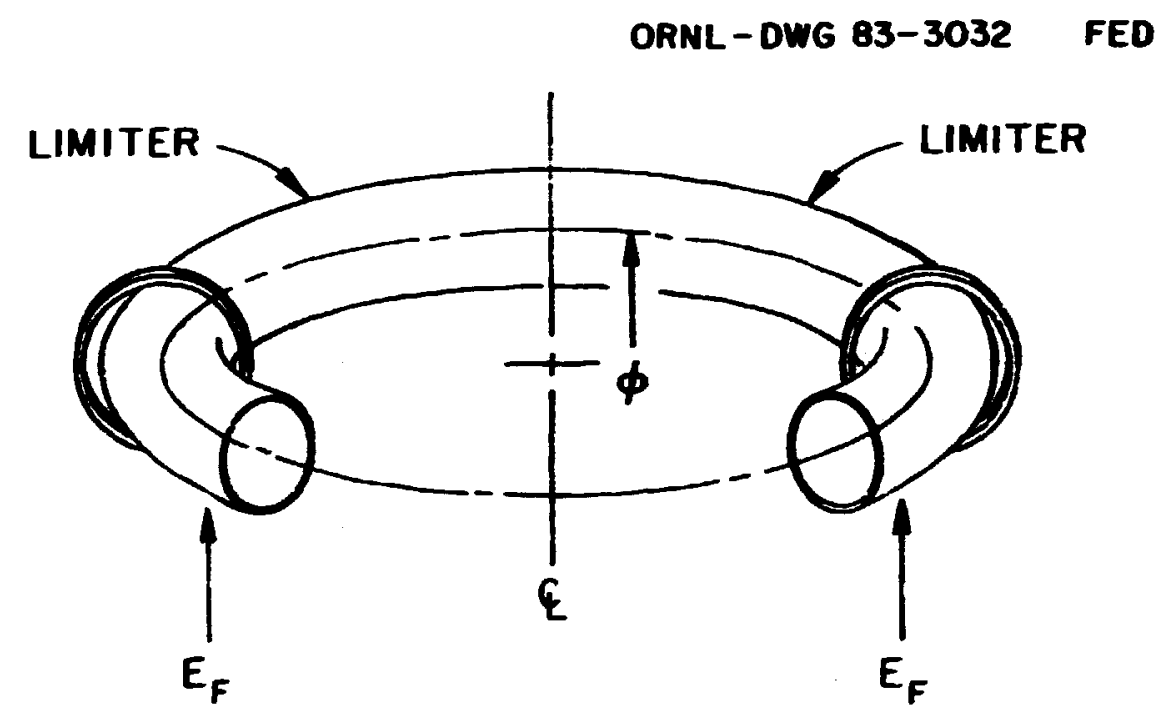

CASE A

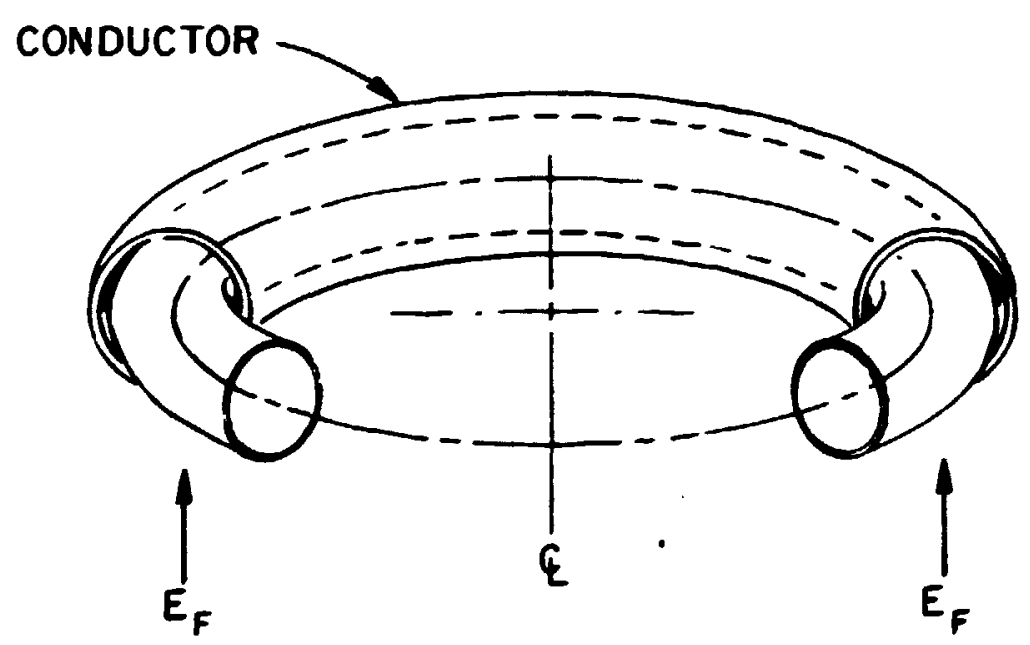

CASE B

Fig. 1. Disruption configuration cases. 
loses its equilibrium due to the thermal disruption effects, it can move into the liniter. Once this inward motion starts, it further reduces the current and equilibrium and speeds the plasea current decay. There is an: ivalanche effect. The process is one in which the plaswa movement inward is linited by the inner radius of the limiter. As the external field decays, its energy goes into ohmically heating the remaining plasna, which in turn deposits the energy thermally on the limiter by conduction. The current decay time is basically how fast the plasma transfers the thermal energy to the limiter.

In case B, which has a good electrical conductor at the wall behind the scrape-off region, the plaswa can move into the wall or limiter, but the external field can te maintained by the vessel eddy currents. In this case, the external stored energy is deposited primarily as $I^{2} R$ heating in the vessel. The melting of the limiters or the vessel walls due to the magnetically stored energy can essentially be eliminated. Note that it isn't really the time decay of the plasma current that is significant in determining the damage to the structures for the case of a major thermal disruption. A fast decay of plisra current is not necessarily damaging. The important factors are actually the time decay of the magnetic field and where the energy is deposited. To be effective in absorbing the external magnetic $c$ ergy, the torus resistance must be low in comparison to the plasma resistance after the thermal decay has occurred.

Two conditions of thermal disruption are presented t's show how the current decay phase of disruption should be considered frum an electromagnetic design viewpoint. The first will be a minor thermal distuption, and the second will be a major thermal disruption. In condition 1 , the plasma will be hot compared to $100 \mathrm{eV}$ following the thermal quench. In this case, the good conducting shell will allow a small powered active position control system to maintair. the current in the center of the vessel. The tokamak could then be shut down normally or the plasma reheated. In condition 2, the temperature folsuwing the thermal quench would be low ( $100 \mathrm{eV}$ or less). In this case, the thermal energy has essentially been dissipated in the limiter and only the magnetic energy remains to inflict additional damage. To maintain the plasma in the 
center of the vessel and to maintain the plasea current, it would require a large power system for heating and to maintain equilibrium. The large influx of impurities would also add to the power required. A better process for handling the major thermal disruption is to absorb the external field energy in the conducting shell near the plasma and prevent the energy from being absorbed as ohnic heating of the plasm. The system can be shut down with no ohaic heating or heating power and the PF coil currents lowered as quickly as possible to further aid in removal of the external lagnetic field energy.

The resistance of the conducting shell near the plaswa should be comparable to the resistance of the plasma at a teaperature of approximately $100 \mathrm{eV}$. In the Fusion Engineering Device (FED) Baseline or DCT-8/ TFCD. this value should be $4.5 \times 10^{-6} \Omega$. Its time constant would be approximately $1 \mathrm{~s}$.

In FED studies, as in ref. 3, a vessel time constant of a half second resulted in a plasma current decay of $30 \mathrm{~ms}$. Ti.e important point is that $98 \%$ of the magnetic ener'gy went into the electrical heating of the wall or the external power system. Only $2 \%$ was directly deposited as thermal energy on the wall surface. The self-stabilization of the conducting wall prevented the plasma from moving quickly into the wall.

with a good conducting wall near the plasma, the curren* decay phase for a minor disruption can be avoided by a feedback control system, which maintains the plasma in equilibrium at the center of the vacuum vessel. With a good conducting passive circuit near the plasma, this can be accomplished with a relatively low power sontrol system. For the FED design, an aceive control system of 32-MH peak (8-MW rms) was adequate to maintain equilibrium in time scales of a few milliseconds. ${ }^{4}$

\section{CONCLUSIONS}

To minimize the ablation and melting of the limiters or walls of a tokamak during disruption, the following steps stould be considered:

(1) For a major thermal disruption, the thermal energy in a hot plasma will essentially be dissipated in the limiter or by radiation.

(2) For a major thermal disruption, the external magnetic energy, 
which is approximately equal to the ignited thermal energy, can be dissipated in a good conducting shell without adding to the plasma thermal heat load on the limiter or first wall surfaces. iny damage can be limited to that produced by the thermal decay phase of disruption.)

(3) The damage due to a minor thermal disruption can be minimized by providing a passive circuit near the plasma. With a shell having a few hundred millisecond time constant, an active feedback control system rated for a few megawats kill be sufficient. ${ }^{3}$ (The active control should provide variations in the equilibrium field and not ohnic heating power.)

(4) With a low impedance shell, high voltages wiil not be produced on coils and structures during a disruption. A low impedance shell will result in less heat on superconducting structures and will reduce arc damage.

(5) The disadvantages of a long time constant structure near the plasma are the possible large energy for startup and the need to provide electrical connections between removable shield segments. Startup should be achievable by utilizing rf with an ohmic heating coil voltage of less than $1: v$ per turn. (This should not be a linitation on the design.)

In thr case of a major disruption, maintaining the plasma current from decaying quickly is not the important factor. Keeping the thermal energy from melting the surfaces and the electromagnetic forces from becoming excessive is important. 
Appendix A. DESIGN OPTIONS FOR REDUCING DISRUPTION DAMAIJE

A-1. The primary objective in preventing disruption dimage is to provide a good conductor adjacent to the plasma that will absorb the external magnetic stored energy. To provide this, a low voltage startur jevelopment is most advantageous. The aim should be to start up with less than $1 V$ per turn provided by the ohmic hea:ing system. Use of rf [electror cyclotron resonance heating (ECPH) and lower hybrid resonance heating (LHRH)] for initially heating the plasma and for current drive should be pursued. Startup with electron-beam-assisting LHRH current drive should also be pursued.

A-2. The plasma circuit should have high resistances during the current decay phase of disruption. There are a number of methods which could provide the advantageous condition:

(a) Pulsing cold gas itto the plasma, especially near the inner walls and limiter.

(b) Injecting excessive fuel pellets to cool the plasma.

(c) Inserting or allowing the plasma to move toward getter material, which would aid in improving the vacuum for the subsequent operations.

(d) Injecting impurities, which would provide large radiation power and thus reduce the energy deposited on the limiter surface.

A-3. The operations could possibly utilize the following:

(a) Driving the plasma toward areas where the thermal cnergy could be safely dissipated.

(b) Using matcrial such as graphite, which withstands transient excessive short period temperatures, for areas such as (a) above. (These need not be in contact with the 
plasma in normal operations.)

(c) Designing the limiter to allow halo or scrape-off regions around the plasma to carry currents during the disruption to control where the heating occurs. [Putting noles and slots in the limiter could result in disruption energy being deposited in the larger areas of the limiter not normaliy in cont-at with the plasma in normal operation (see Fig. A. I; . ]

(d) Subdividing the limiter in the toroidal direction to prov:de larger impedance paths through the limiters 5 (wi:h less current and heat produced in limiters).

A-4. On existing machines such as the Tokamak Fusion Test Reactor (TFT.i), disruption damage may be reduced by the fol'owing:

(a) Shorting out as many bellows or instilating breaks as possible with straps of tungsten, which have lower resistance than the bellc:rs.

(b) Providing good toroidal conductors, which are open circuited during startup but are closed after startup.

(c) Installing toroidal bus bars external to the vacuum vesse1. Switches required to complete the circuit after startup may be mechanical or solid-state semiconductors.

The position of these conductors in (c) above could assist in controlling the position of the plasma during the current decay phase, which could result in depositing of the magnetic energy at a desirable location. 


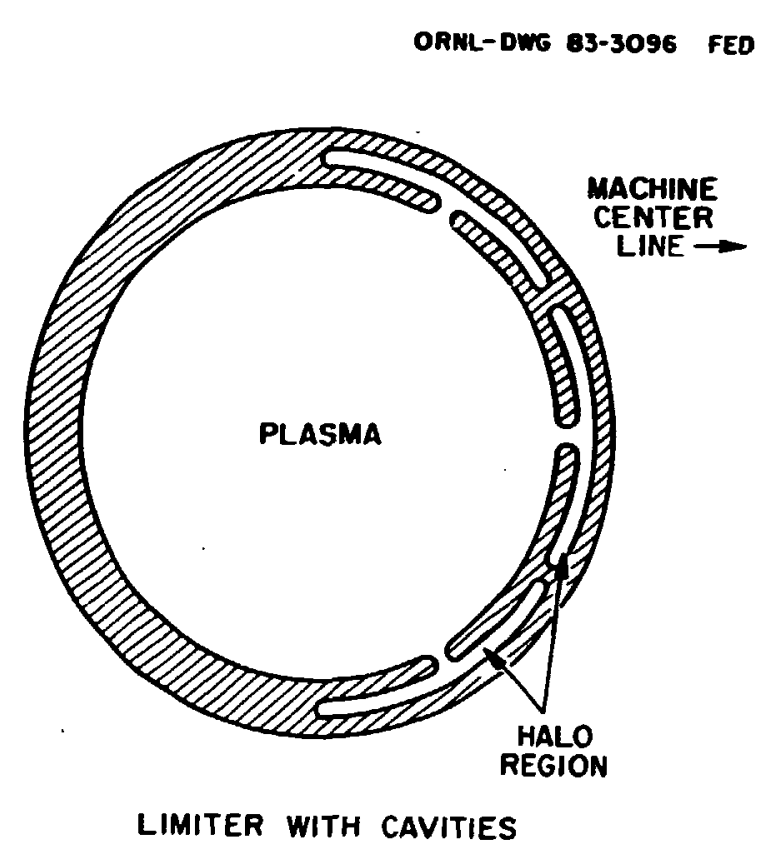

Fig. A.1. Toroidal limiter configuration. 


\section{REFERENCES}

1. W. M. Stacey, Jr., T. E. Shannon, et al., U.S. FED-INTOR Activity and U.S. Contribution to the International Tokanak Reactor Phase 2A Workshop, Critical Issues, Vols. I and II, USA-FED-INTOR/82-1, Vienna, Austria, 1982.

2. Tihiro Ohkawa, Annual Report to DOE of the General Atomic Company, Fusion Program, GA-A16816, 1981.

3. J. G. Murray and G. Bronner, Dismution Model, PPPL-1909, Princeton Plasma Physics Lab., Princeton University, 1982.

4. J. G. Murray and G. Bronner, "FED Control Power," in Proceedings of the 9th Symposium on Engineering Problems of Fusion Research, IEEE, Chicago, Illinois (1981).

5. R. W. Moiley, Active Tokamak Limiter Symmetrizing the Edge Plasma, PPPL-1743, Princeton Plasma Physics Lab., Princeton University, February 1981. 
ORNL/FEDC-83/5

Dist. Category UC-20 c,d

\section{INTERNAL DISTRIBUTION}

1. T. G. Brown

2. B. Carreras

- B. A. Cramer

4. E. C. Crume, Ir.

5. J. L. Dunlap

6. C. A. Flanagan

7. G. M. Fuller

8. G. E. Gorker

9. J. Haines

10. J. T. Hogan

11. J. Kirchner

12. D. H. Metzler

13-17. J. G. Murray

18. G. H. Neilson

19. W. T. Reierson

20. J. A. Rome

21. M. J. Saltmarsh

22. T. E. Shannon

23. J. Sheffield
26. V. C. Srivastava

25. N. A. Uckan

26. T. Uckan

27. L. M. Hively

28. V. D. Lee

29. J. A. O'Toole

30. Y-K. M. Peng

31. K. E. Rothe

32. F. W. Wiffen

33-34. Laboratory Records Department

35. Laboratory Records, ORNL-RC

36. Document Keference Section

37. Central Research Library

38. Fusion Energy Division Library

39. Fusion Energy Division Reports Office

4J. ORNL Patent office

\section{EXTERNAL DISTRIBUTION}

41. M. A. Abdou, Associate Director, FPP/207, Argonne National Laboratory, 9700 South Cass Avenue, Argonne, IL 60439

42. N. A. Amherd, Fusion Power Program, Advanced Systems Department, Electric Power Research Institute, P.O. Box 10412, Palo Alto, CA 94304

43. J. L. Anderson, CMB-3, Mail Stop 348, Los Alamos National Laboratory, P.0. Box 1663, Los Alamos, NM 87545

44. M. Anderson, Tennessee Valley Authority, 1300 Comnerce Bank Building, Building, Chat tanooga, TN 37401

45. 0. A. Anderson, Lawrence Berke!ey Laboratory, University of California, Berkeley, CA 94720

46. D. J. Anthony, Advanced Power Program, Advanced Energy Programs Department, Building 2, Room 551, General Electric Company, Schenectady, NY 12345

47. C. C. Baker, FPP/208, Argonne National Laboratory, 9700 South Cass Avenue, Argonne, IL 60439

48. T. H. Batzer, L-536, Lawrence Livermore National Laboratory, P. 0. Box 808, Livermore, CA 94550

49. J. E. Baublitz, Office of Fusion Energy, Department of Energy, Washington, DC 20545

50. W. Bauer, Physical Research Division, Sandia National LaboratoriesLivermore, Livermore, CA 94550 
51. J. F. Baur, GA Technologies, Inc., P.0. Box 81608, San Diego, CA 92138

52. D. S. Beard, Office of Fusion Energy, Office of Energy Research, Mai 1 Stop G-256, U.S. Department of Energy, Washington, DC 20545

53. R. J. Beeley, ETEC, Rockwell International, P.0. Box 1449, Canoga Park, C.' 91304

54. D. C. Berkey, Vice President E General Manager, Energy System and Technology Division, General Electric Company, P.0. Box 7600, Stamford, CT 06904

55. K. L. Black, Department E452, McDonnell Douglas Astronautics Company, P.0. Box 516, St. Louis, MO 63166

56. R. Botwin, C47-05, Grumman Aerospace Corporation, P.0. Box 31, Bethpage, NY 11714

57. H. B. Briggs, McLonnell Douglas Astronautics Company, P.0. Box 516, St. Louis, MO 63166

58. G. Bronner, Princeton Plasma Physics Laboratory, P.0. Box 451, Princeton, NJ 085 $\$ 4$

59. J. N. Brooks, FPP/207, Argonne National Laboratory, 9700 South Cass Avenue, Argonne, IL 60439

60. S. C. Burnett, GA Technologies, Inc., P.0. Box 81608, San Diego, CA 92138

61. J. D. Callen, Department of Nuclear Engineering, University of Wisconsin, Madison, WI 53706

62. V. S. Chan, GA Technologies, Inc., P.0. Box 81608, San Diego, CA 92138

63. R. G. Clemmer, Fusion Power Program, Argonne National Laboratory, 9700 South Cass Avenue, Arronne, IL 60439

64. D. R. Cohn, MIT Plasma Fusion Center, 167 Albany Street, Cambridge, MA 02139

65. W. S. Cooper, Lawrence Berkeley Laboratory, University of California, Berkeley, CA 94720

66. J. W. Coursen, C36-05, Grumnan Aerospace Corporation, P.0. Box 31, Bethpage, NY 11714

67. R. W. Conn, School of Chemical, Nuclear, and Thermal Engineering, Boelter Hall, University of California, Los Angeles, CA 90024

68. J. G. Crocker, EGEG Idaho, P.0. Box 1625, Idaho Falls, ID 83401

69. A. E. Dabiri, Energy Systems and Conservation Division, Science Applications, Inc., P.0. Box 2351, La Jolla, CA 92038

70. C. C. Damm, L-441, Lawrence Livermore National Laboratory, P. 0. Box 808, Livermore, CA 94550

71. R. C. Davidson, Massachusetts Institute of Technology, 77 Massachusetts Avenue, Cambridge, MA 02139

72. N. A. Davies, Office of Fusion Energy, Office of Energy Research, Mail Station G-256, U.S. Department of Energy, Washington, DC 20545

73. J. W. Davis, E457, Building 81/1/B7, McDonnell Douglas Astronautics Company, P.O. Bux 516, St. Louis, MO 63166

74. M. J. Davis, Sandia National Laboratories, P.0. Box 5800, Albuquerque, NM 87185

75. S. 0. Dean, Director, Fusion Energy Development, Science Applications, Inc., 2 Professional Drive, Suite 249, Gaithersburg, MD 20760 
76. J. F. Decker, Office of Fusion Energy, Department of Energy, Mail Stop G-256, Washington, DC 20545

77. D. DeFreece, E451, Building 81/1/B7, McDonnell Douglas Astronautics Company, P.0. Box 516, St. Louis, MO 63166

78. A. Deitz, Princeton Plasma Physics Laboratory, P.0. Box 451, Princeton, NJ 08544

79. D. A. Dingee, Program Manager, Fusion Technology, Pacific Northwest Laboratories, Battelle Boulevard, Richland, WA 99352

80. J. N. Doggett, L-441, Lawrt. ce Livermore National Laboratory, P.o. Box 808, Livermore, CA 94550

81. H. Dreicer, Division Leader, CRT, Los Alamos National Laboratory, P.U. Box 1663, Los Alamos, NM 87545

82. D. Ehst, Argonne National Laboratory, 9700 South Cass Avenue, Argonne, IL 69439

83. G. A. Eliseev, I. V. Kurchatev Institute of Atomic Energy, P.0. Bnx 3402, 123182 Moscow, U.S.S.R.

84. W. R. Ellis, Office of Fusior. Energy, Department of Energy, Mail Stop G-256, Washington, DC 20545

85. B. A. Engho!m, GA Technologies, Inc., P.0. Box 81608, San Diego, CA 92138

86. H. P. Eubank, Princeton Plasma Physics Laboratory, P.0. Box 451, Princeton, NJ 08544

81. F. Farfaletti-Casali, Engineering Division, Joint Research Center, Ispra Establishment, 21020 Ispra (Varese), Italy

88. J. J. Ferrante, Manager, Building 36-241, Large Superconducting Program, General Electric Company, I River Road, Schenectady, NY 12345

89. J. File, Princeton Plasma Physics Laboratory, P.0. Box 451, Station G-256, U.S. Department of Energy, Washington, DC 20545

90. P. A. Finn, Fusion Power Program, Argonne Nationa! Laboratory, 9-00 South Cass Avenue, Argonne, IL 60439

91. H. K. Forsen, Bechtel Group, Inc., Research \& Engineering, P.0. Box 3965, San Francisco, C1 94119

92. J. S. Foster, Jr., Bui ding R4-2004, TKW Defense and Space Systems, 1 Space Park, Redondo Beach, CA 90278

93. T. K. Fowler, Associate Director for MFE. L-436, Lawrence Livermore National Laboratory, P.0. Box 808, Livermore, CA 94550

94. J. W. French, EBASCO Services, Inc., Forrestal Campus, CN-59, Princeton University, Princeton, NJ 08544

95. H. P. Furth, Director, Princeton Plasma Physics Laboratory, P.0. Box 451, Princeton, NJ 08544

96. J. G. Gavin, Jr., President, A01-11, Grumman Aerospace Corporation, P.0. Box 31, Bethpage, NY 11714

97. G. Gibson, Westinghouse Electric Corporation, Fusion Power Systems Department, P.O. Box 10864, Pittsburgh, PA 15236

98. J. R. Gilleland, Manager, Fusion Project, GA Technologies, Inc., P.0. Box 81608, San Diego, CA 92138

99. V. A. Glukhikh, Scientific-Research Institute of Electro-Physical Apparatus, 188631 Leningrad, U.S.S.R. 
100. M. Y. Gohar, Argonne National Laboratory, 9700 South Cass Avenue, Argonne, IL 60439

101. W. D. Goins, Tennessee Valley Authority, 1300 Comerce Union Bank Building, Chattanooga, TN 37401

102. D. A. Goldberg, Lawrence Berkeley Laboratory, University of California, Berkeley, CA 94720

103. R. Goldston, Princetcn Plaswa Physics Laboratory, P.0. Bux 451, Princeton, NJ 08544

104. M. B. Gottlieb, Princeton Plasma Physics Laboratory, P.0. Box 451, Princeton, NJ 08544

105. R. W. Gould, Department of Applied Physics, California Institute of Technology, Pasadena, CA 91109

106. M. W. Griffin, Department E236, McDonnell Douglas Astronautics Corpany, P.O. Box 516, St. Louis, MO 63166

16?. C. R. Head, Office of Fusion Energy, Department of Energy, Mail Stop G-256, Washington, $\mathrm{DC} 20545$

108. C. D. Hicnning, Lawrence Livermore National Laboratory, P.0. Box 808, Liverwore, CA 94550

109. G. K. Hess, Office of Fusion Energy, Department of Energy, Mail Stop ER-701, Washington, DC 20545

110. T. Hiraoka, JT-60 Project Office I, Japan Atomic Energy Research Institute, Tokai Research Establishment, Tokai, Ibaraki, Japan

111. k. L. Hirsch, Manager, Synthetic Fuels Research, Exxon Research and Engineering Company, P.O. Bcx 4255, Baytown. TX 77520

112. J. J. Holmes, West inghouse-Hanford Engineering Development Laboratory, P.0. Box 1970, Richland, WA 99352

113. W. G. Homeyer, GA Technologies, Inc., P.0. Box 81608, San Diego, CA 92138

114. J. C. Hosea, Princeton Plasma Physics Laboratory, P.0. Box 451, Princeton, NJ 08544

115. D. Hwang, Princeton Plasma Physics Laboratory, P.0. Box 151, Princeton, NJ 08544

116. G. J. Inukai, Department E231, McDonnell Doug las Astronautics Company, P.0. Box 516, St. Louis, MO 63166

117. D. L. Jassby, Princeton Plasma Physics Laboratory, P.0. Box 451, Princeton, NJ 08544

118. J. B. Joyce, Princeton Plasma Physics Laboratory, P.0. Box 451, Princeton, NJ $\mathbf{9 8 5 4 4}$

119. R. A. Krakowski, CTR-12, Mail Stop 641, Los Alamos National Laboratory, P.0. Box 1663, Los Alamos, NM 87545

120. G. L. Kulcinski, University of Wisconsin, Department of Nuclear Engineering, Engineering Research Building, Room 439, 1500 Johnson Drive, Madison, WI 53706

121. D. L. Kummer, McDonnel. Douglas Astronautics Corapany, P.0. Box 516, St. Louis, MO 63166

122. T. S. Latham, Mail Stop 44, United Technologies Research Center, Silver Lane, East Hartford, CT 06108

123. L. R. Ledman, Office of Fusion Energy, Department of Energy, Mail Stop G-256, Washingtnn, DC 20545

124. L. M. lidsky, MIT Plasina Fusion Center, 167 Albany Street, Cambridge, MA 02139 
125. C. S. Liu, GA Technologies, Inc., P.0. Box 81608, San Diegn, CA 92138

126. E. F. Lowell, General Manager, Energy Systems Programs Departaent, Building 2-455, General Electric Company, 1 River Road, Schenectady, NY 12345

127. D. J. McFarlin, Mail Stop 44, United Technologies Research Center, Silver Lane, East Hartford, CT 06108

128. R. McGrath, Fusion Power Program, Argonne National Laboratory, 9700 South Cass Avenue, Argonne, IL 60439

129. V. A. Maroni, CEN/205, Argonne National Laboratory, 9700 South Cass Avenue, Argonne, ' $\mathrm{L} 60439$

130. W. Marton, Office of Fusion Energy, Office of Energy Research, Mail Station G-256, U.S. Department of Energy, Washington, DC 20545

131. L. G. Masson, EG\&G Idaho, Idaho National Engineering Laboratory, P.0. Box 1625, Idaho Falls, ID 83401

132. D. G. McAlees, Exxon Nuclear Company, Inc., 777 106th Avenue, NE, Bellevue, WA 98009

133. D. M. Meade, Princeton Plasma Physics Laboratory, P.0. Box 451, Princeton, NJ 08544

134. A. T. Mense, Building 107, Post B2, McDonnell Douglas Astronautics Company, P.0. Box 516, St. Louis, MO 63166

135. L. Michaels, Princeton Plasma Physics Laboratory, P.0. Box 451, Princeton, NJ 08544

136. D. Mikkelsen, Princeton Plasma Physics Laboratory, P.0. Box 451, Princeton, NJ 08544

137. R. L. Miller, GA Technologies, Inc., P.0. Box 91608, Sa: Diego, CA 92138

138. R. G. Mills, Frinceton Plasma Physics Laboratory, P.0. Box 451, Princeton, NJ 08544

139. J. T. D. Mitchel 1, Culham Laboratory, Abingdon, Oxon Ox14 3DB, United Kingdom

140. R. W. Moir, Lawrence Livermore National J.aboratory, P.0. Box 808, Livermore, CA 94550

141. D. B. Montgomery, MIT Plasma Fusion Center, 167 Albany Street, Cambridge, MA 02139

142. K. :oses, R-1/1078, TRW Defense and Space Systems, I Space Park, Recondo Beach, CA 90278

143. R. E. Musler, Aerojet Manufacturing Company, P.0. Box 4210, Fullerton, CA 92934

144. A. E. Munier, Grumman Aerospace Company, P.0. Box 31, Bethpage, NY 11714

145. M. R. Murphy, Office of Fusion Energy, Department of Energy, Washington, DC 20545

146. R. E. Nygren, FPP/207, Argonne National Laboratory, 9700 South Cass Avenue, Argonne, IL 60439

147. T. Ohkawa, GA Technologies, Inc., P.0. Box 81608, San Diego, CA 92138

148. M. Okabayashi, Princeton Plasma Physics Laboratory, P.0. Box 451, Princeton, NJ 08544

149. D. Overskei, GA Technologies, Inc., P.0. Box 81608, San Diego, CA 92138

150. R. R. Parker, Francis Bitter National Magnet Laboratory, 170 A! uany Street, Cambridge, MA 02139 
151. B. Pease, Culhan Laboratory, Abingdon, Oxon 0x14 3nB, United Kingdom

152. M. Pelovitz, Princeton Plasma Physics Laboratory, I .0. Box 451, Princeton, NJ 08544

153. F. W. Perkins, Princeton Plasma Physics Laboratory, P.0. Box 451, Princeton, NJ 08544

154. M. Petravic, Princeton Plasaa Physics Laboratory, P.0. Box 451, Princeton, NJ 08544

155. M. Porkolab, Massachusetts Institute of Technology, 77 Massachuse:ts Avenue, Cambridge, MA 02139

156. D. E. Post, Princeton Plasea Physics Laboratory, P.0. Box 451, Princeton, NJ 08544

157. L. K. Price, Department of Energy, Oai pidge Operations, P.o. Box E, Oak Ridge, TN 37830

158. R. E. Price, Office of Fusion Energy, office of Energy Research, Mail Station G-256, Nashington, DC 20545

159. D. H. Priester, Office of Fusion Energy, Department of Energy, Washington, DC 20545

160. F. A. Puhn, GA Technologies, Inc., P.0. Box 81608, San Diego, CA 92138

161. J. Purcel1, GA Technologies, Inc., P.0. Box 81608, San Diego, CA 92138

162. R. V. Pyle, University of Californir,, Lawrence Berkeley Laboratory, Berkeley, CA 94720

163. J. M. Rawls, GA Technologies, Inc., P.0. Box 81608, San Diego, CA 92138

164. P. J. Reardon, Princeton Plasma Physics Laboratory, P.0. Box 451, Princeton, NJ 08544

165. M. Roberts, Office of Fusion Fnergy, Department of Energy, Mail Stop G-256, Washington, DC 20545

166. J. D. Rogers, Los Alamos National Laboratory, P.0. Box 1663, Los Alamos, NM 87545

167. F. L. Robinson, Tennessee Valley Authority, 1300 Commerce Bank Building, Chattanooga, TN 37401

168. M. L. Rogers, Monsanto Research Corporation, Mound Litboratory Facility, P.0. Box 32, Miamisburg, OH 45342

169. M. N. Rosenbluth, RLM 11.218, Institute for Fusion Studies, University of Texas, Austin, TX 78712

170. L. Ruby, Lawrence Berkeley Laboratory, University of California, Berkeley, CA 94720

171. P. H. Rutherford, Princeton Plasma Physics Laboratory, P.0. Box 451, Princeton, NJ 08544

172. D. D. Ryutov, Institute of Nuclear Physics, Siberian Branch of the Academy of Sciences of the U.S.S.R., Sovetskaya St. 5, 630090 Novosibirsk, U.S.S.R.

173. M. M. Sabado, EBASCO Services, Inc., A Site, Building 1-A, Forrestal Campus, Princeton, NJ 08544

174. J. A. Schmidt, Princeton Plasma Physics Laboratory, P.0. Box 451, Princeton, NJ 08544

175. J. Schultz, MIT Plasma Fusion Center, 167 Albany Street, Cambridge, MA 02139

176. F. .. Scott, Electric Power Research Institute, P.O. Box 10412, Palo Alto, CA 94304 
177. G. Sheffield, Princeton Plasma Physics Laboratory, P.0. Box 451, Princeton, NJ 08544

178. C. E. Singer, Princeton Plaswa Physics Laboratory, P.0. Box 451, Princeton, NU 08544

179. T. J. M. Sluyters, Accelerator Department, Brookhaven National Laboratory, Upton, NY 11973

180. D. Smith, Materials Science Division, Argonne National Laboratory, 9700 South Cass Avenue, Argonne, IL 60439

181. G. E. Snith, Gruman Aerospace Corporation, P.0. Box 31, Bethpage, NY 11714

182. R. I. Smith, Board Chairnan, Public Service Electric and Gas Company, 80 Park Place, Newark, NJ 07101

183. L. Soroka, Lawrence Berkeley Laboratory, University of California, Berkeley, CA 94720

184. L. Southworth, GA Technologies, Inc., P.0. Box 81608, San Diego, CA 92138

185. I. Spighel, Lebedev Physical Institute, Leninsky Prospect 53, 117924 Moscow, U.S.S.R.

186. W. M. Stacey, Jr., Georgia Institute of Technology, School of Nuclear Engineering, Atlanta, GA 30332

187. E. Stern, Grumman Aerospace Corporation, CN-59, Forrestal Campus, Princeton, NJ 08544

188. L. D. Stewart, Princeton Plasma Physics Laboratory, P.0. Box 451, Princeton, NJ 08544

189. W. Stodiek, Princeton rlasma Physics Laboratcry, P.0. Box 451, Princeton, NJ 0854:

190. P. M. Stone, Office of Fusion Energy, Office of Energy Research, Mail Station G-256, Washington, DC 20545

19]. I. N. Sviatoslavsky, Room 33, Engineering Research Building, 1500 Johnson Drive, University of Wisconsin, Madison, WI 53706

192. T. Tamano, GA Technologies, Inc., P.0. Box 81608, San Diego, CA 92158

193. R. E. Tatro, Manager, Energy Systems, M.2. 16-1070, Ge.7eral DynamicsConvair Division, P.C. Box 80847, San Riezo, CA 92138

194. F. Tenney, Princeton Plasma Physics Laboratory, P.0. Bcx 451, Princeton, NJ 08544

195. F. Thomas, B-20-5, Grumman Aerospace Corporation, Bethpage, NY 11714

196. K. I. Thomassen, Lawrence Livermore National Laboratory, P.0. Box 808, Livermore, CA 94550

197. R. J. Thome, Francis Bitter National Magnet Laboratory, 170 Albany Street, Cambridge, MA 02139

198. S. L. Thomson, Bechtel Group, Inc., P.0. Box 3965, San Francisco, CA 94119

199. V. T. Tolok, Kharkov Physical-Technical Institute, Academical St. 1, 310108 Kharkov, U.S.S.R.

200. C. Trachsel, McDonnell Douglas Astronautics Company, P.0. Box 516, St. Louis, Mo 63166

201. J. R. Treglío, General Dynamics-Convair Division, P.0. Box 80847, San Diego, CA 92138

202. A. W. Trivelpiece, Office of Energy Research, Department of Energy, Washington, DC 20545 
203. L. R. Turner, Fusion Power Program, Argonne National Laboratory, 9700 South Cass Avenue, Argonne, IL 60439

204. M. A. Ulrickson. Princeton Plasma Physics Laboratory, P.0. Box 451, Princeton, NJ 08544

205. E. H. Valeo, Princeton Plasma Physics Laboratory, P.0. Box 451, Princeton, NJ 08544

206. T. C. Varljen, Westinghouse Electric Corporation, P.0. Box 10864, Pittsburgh, PA 15236

207. R. Varma, Physical Research Laboratory, Navangpura, Ahmedabad, India

208. H. F. Vogel, Los Alamos National Laboratory, P.0. Box 1663, Los Alamos, NA 87545

209. A. Wait, Building 36-421, General Electric Company, 1 River Road, Schenectady, NY 12345

210. K. E. Nakefield, Princeton Plasma Physics Laboratory, P.0. Box 451, Princeton, NJ 08544

211. D. Neldon, Los Alamos National Laboratory, P.J. Box 1663, Los Alamos, NM 87545

212. J. C. Wesley, GA Technologies, Inc., P.0. Box 81608, San Diego, CA 92138

213. S. Whitley, Tennessee Valley Authority, 1300 Comoerce Bank Building, Chat tanooga, TN 37401

214. W. R. Wilkes, Monsanto Research Corporation, Mound Laboratory Facility, P.0. Box 32, Miamisburg, OH 45342

215. J. E. Wilkins, EG\&G Idaho, Idaho National Engineering Laboratory, P.0. Box 1625, Idaho Falls, ID 83401

216. H. Willenberg, Mathematical Scierces Northwest, Inc., P.0. Box 1887, Bellevue, WA 98009

217. J. E. C. Williams, Francis Bitter National Magnet Laboratory, 170 Albany Street, Cambridge, MA 02139

218. P. Willis, Building 23, Room 298, General Electric Company, 1 River Road, Schenectady, NY 12345

219. T. F. Yang, MIT Plasma Fusion Center, 167 Albany Street, Cambridge, MA 02139

220. H. H. Yoshikawa, W/A-62, Hanford Engineering Development Laboratory, P.0. Box 1970, Richland, WA 99352

221. K. M. Young, Princeton Plasma Physics Laboratory, P.0. Box 451, Princeton, N.J 08544

222. N. E. Young, EBASCO Services, Inc., Princeton Plasma Physics Laboratory, P.O. Box 451, Princeton, NJ 08544

223. K. M. Zwilsky, National Materials Advisory Board, Naticnal Academy of Science;, 2101 Constitution Avenue NW, Washington, DC 20418

224. Bibliothek, Max-Planck Institut fur Plasmaphysik, D-8046 Garching bei Munchen, Federal Republic of Germany

225. Bibliothek, Institut fur Plasmaphysik, KFA, Postfach 1913, D-5170 Julich, Federal Republic of Germany

226. Bibliotheque, Centre de Recherches en Physique des Plasmas, 21 Avenue des Bains, 1007 Lausanne, Switzerland

227. Bibliotheque, Service du Confinement des Plasmas, CEA, B.P. No. 6, 92 Fontenay-aux-Roses (Seine), France

228. Documentation S.I.G.N., Department de la Physique du Plasma et de la Fusion Controlee, Association EURATOM-CEA, Centre d'Etudes Nucleaires, B.P. 85, Centre du Tri, 38041 Grenoble, Cedex, France 
229. Library, Centre de Recherches en Physique des Plasmas, 21 Avenue des Bains, 1007 Lausanne, Switzerland

230. Library, Culhan Labora* Jry, UKAEA, Abingdon, Oxon, Ox14 3DB, England

231. Library, fOM Institut voor Plasea-Fysica, Rijnhuizen, Jutphaas, Netherlands

232. Library, Institute of Physics, Acadenia Sinica, Beijing, Peoples Republic of China

233. Library, Institute for Plasma Physics, Nagoya University, Nagoya 464, Japan

234. Library, International Centre for Theoretical Physics, Trieste, Italy

235. Library, JET Joint Undertaking, Abingdon, Oxfordshire, OX14, DB, England

236. Library, Laboratoria Gas Ionizzati, Frascati, Italy

237. Plasma Research Laboratory, Australian National University, P.0. Box 4, Canberra, ACT 2000, Australia

238. Thermonuclear Library, Japan Atomic Energy Research Institute, Tokai, Naka, Ibaraki, Japan

239. Library, Plasma Physics Laboratory, Kyoto University, Gokasho Uji, Kyotu, Japan

240. Office of the Assistant Manager for Energy Research and Development, Department of Energy, Oak Ridge Operations, Oak Ridge, TN 37830

241-479. Given distribution as shown in TID-4500, Magnetic Fusion Encrgy, (Distribution Cate zory UC-20 c,d: Reactor Materials ard :usion Systems) 